\title{
Can America Escape Plutocracy?
}

\begin{abstract}
The first step in solving a problem is to admit it exists. If the US is to escape plutocracy, it must first ask itself painful questions about the pervasive influence of wealth in its politics.
\end{abstract}

Throughout human history, wise men have warned of the dangers of plutocracy. In Plato's Republic, Socrates warned of the dangers of selecting captains of ships by their wealth. Teddy Roosevelt also warned, "of all forms of tyranny, the least attractive and most vulgar is the tyranny of mere wealth, the tyranny of a plutocracy." Yet despite these warnings, America has gone from democracy toward becoming, for all practical purposes, a plutocracy, moving away from a government of the people, by the people and for the people to a government "of the $1 \%$, by the $1 \%$ and for the $1 \%$," as noted by the Nobel Laureate Joseph Stiglitz.

What's the evidence for this claim? It's massive. The wealthy have seized most of the new wealth. Anand Giridharadas, a former New York Times columnist, has observed that in terms of income increase since 1980, "that of the top $1 \%$ has more than tripled and that of the top $0.001 \%$ has risen more than seven fold-even as the average pretax income of the bottom half of Americans has stayed almost precisely the same." But the wealthy are not satisfied with seizing more wealth. They are also seizing political power. Two Princeton University political scientists, Gilens and Page, have documented in detail how political outcomes in America reflect the interests of the wealthy, not the mass voters. Hence, they sadly conclude "in the United States, our findings indicate, the majority does not rule-at least not in the causal sense of actually determining policy outcomes."

How did the $1 \%$ seize both greater political and economic control in America? The answer is complex. The slide began with Ronald Reagan saying that "government is not the solution; government is the problem." In most countries, especially in Europe, governments play a critical role in counter-balancing market forces and ensuring a level playing field for all citizens. By weakening the government, America has also taken away equality of opportunity. The result, as Edward Luce says, is that "studies show that an eighth grade (14-year-old) child from a lower income bracket who

Originally published in The Diplomat, Sept 28, 2020 
achieves maths results in the top quarter is less likely to graduate than a kid in the upper income bracket scored in the bottom quarter. This is the reverse of how meritocracy should work."

The power of money in determining political outcomes in America was given a major boost by the Supreme Court's "Citizens United" decision of January 2010. It gave those with money the green light to spend unlimited sums on ads and other political tools to ensure the election of candidates sensitive to their interests. Martin Wolf says the "the Supreme Court's perverse 2010 'Citizens United' decision held that companies are persons and money is speech. This has proved a big step on the journey toward becoming a plutocracy."

Living in Athens 2400 years ago, Socrates warned that cities that allowed themselves to be ruled by the wealthy would have a "poor voyage." This is exactly what has happened to America. The latest Social Progress Index, which measures wellbeing in societies across several dimensions, shows that America is the only major developed society that has seen a deterioration in human well-being in many areas. It slipped from number 19 position in 2011 to number 28 in 2020. Nicholas Kristof links this deterioration to "deaths of despair," commenting sadly that one-quarter of the kids who rode his school bus are now dead from drugs, alcohol, and suicide. Two Princeton university economists, Case and Deaton, have also documented that there is a "sea of despair" among working-class Americans.

The existential question that American society faces today is whether it can escape from the clutches of plutocracy after it has taken hold of American society. The only brutally honest answer that one can give to these painful questions is no. Why not? To deal with a problem, one must first acknowledge that there is a problem to deal with. Currently, even though America has the world's freest and most freely independent media, no major newspaper calls America a plutocracy. Neither do the best universities in the world. Americans believe in calling a spade a spade. Yet, if any leading American politician were to call the American plutocracy a plutocracy, he would be committing political suicide. No physician can heal a patient who fails to take the necessary bitter medicine.

America will certainly have to administer bitter medicine to itself to escape from plutocracy. It will have to overturn the Citizens United Supreme Court decision. Like its fellow democracies in Europe, it will have to impose strict limits on the use of money in elections. It will also have to reverse the Reagan-Thatcher intellectual revolution and reach a rock solid consensus that "government is the solution, not the problem." To make government the solution, the pay and prestige of senior government officials will have to be increased. The leading graduates of Harvard and Yale should aspire to join the government, not Goldman Sachs or Chase Bank. Sadly, none of this will happen. America will remain a plutocracy. 
Open Access This chapter is licensed under the terms of the Creative Commons AttributionNonCommercial-NoDerivatives 4.0 International License (http://creativecommons.org/licenses/bync-nd/4.0/), which permits any noncommercial use, sharing, distribution and reproduction in any medium or format, as long as you give appropriate credit to the original author(s) and the source, provide a link to the Creative Commons license and indicate if you modified the licensed material. You do not have permission under this license to share adapted material derived from this chapter or parts of it.

The images or other third party material in this chapter are included in the chapter's Creative Commons license, unless indicated otherwise in a credit line to the material. If material is not included in the chapter's Creative Commons license and your intended use is not permitted by statutory regulation or exceeds the permitted use, you will need to obtain permission directly from the copyright holder.

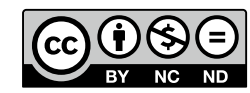

